Paper

\title{
A study of the modeling of fashion in social science and natural science
}

\section{自然科学と社会科学における流行モデル研究}

\author{
Junichi NAKAJIMA \\ Department of Mass Communication, Tokai University, 1117 Kitakaname, Hiratsuka, Kanagawa, 259-1207 JAPAN \\ TEL:81-463-58-1211 (EXT.3153)
}

(Received 19, January 2000 Accepted 10, July 2000)

\begin{abstract}
This paper attempts to show that some methods of natural science can be utilized in sociological studies to analyze and formulate the whole process of fashion. As sociologist Tarde predicted a century ago, a custom-based society in the past has been transformed into a fashion-based society. There can be found numerous forms of fashion in almost every field of our daily life. Fashion is now recognized as being highly influential even in a nation's economy. Little is known, however, about the mechanism which controls the rise and fall of fashion. Its obscurity and formlessness has discouraged scholars from dealing with fashion as an object of academic researches. To break the deadlock, the modeling of fashion as a social phenomenon is indispensable.
\end{abstract}

Keywords :Fashion, Epidemics

社会学者タルドは、慣習が支配する時代から流行が支 配する社会へと転じると 1 世紀前に予測したが、現代社 会はまさに流行社会と化している観がある。ファッショ ンの流行は言うに及ばず、クルマから菓子類に至るまで、 われわれの日常生活を取りまくあらゆる物に流行現象が 見られ、その影響力も大きい。しかしながらこの流行の 発生についてのメカニズムは、いまだに未知の部分が多 い。今日の経済社会に大きな影響力を与えその研究も急 がれる流行現象であるが、不定形で捉えがたいその特性 から、流行研究は必ずしも活発であるとは言いがたい。

本論では流行研究において豊富な実証研究の経験と蓄 積のある自然科学を範として、社会科学にフィードバッ クできモデル構築の手がかりとなる部分がないかを考察 するものである。

\section{FASHION PHENOMENON IN MEDIA}

\section{A. Fashion used in printed media}

毎日の新聞紙上には、さまざまな分野の流行現象が記 事になって紹介されている。新聞という活字メディアは、 各世代の幅広い読者に、不特定多数の興味や関心を集め るということを前提にした紙面作りをしているので、そ れを考えると、流行現象が比較的かたよりなく一般的な 意味で使用されている例を見るのに、格好の素材といえ る。

筆者は朝日新聞のデータをもとに、'1 1946 年から 1994 年までのほぼ戦後 50 年間の総記事を対象とし て、流行に関する全記事の検索を行った。全国版の朝刊 と夕刊で見出しに、〈流行〉というキーワードが出てくる 記事すべてを検索の対象とし、その記事数を、年度別（5 年単位)に整理してみた。(Fig. 1)

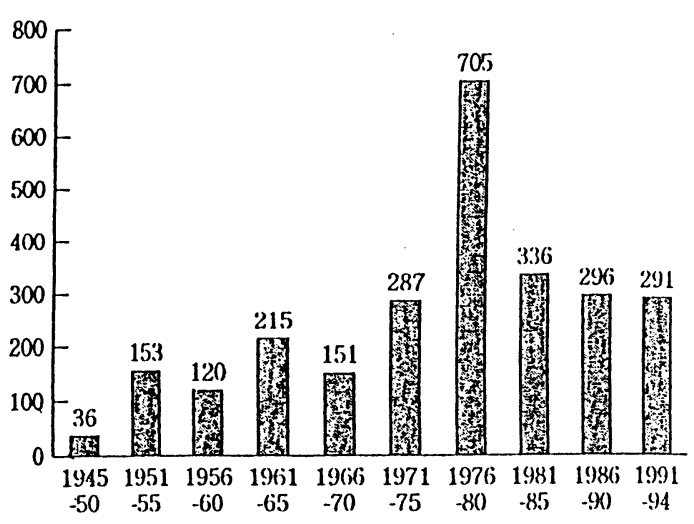

FIG. 1. Nubmers of fashion articles in newspapers during 50 years (1945-1995). Analyzed by author.

1970 年代後半の時期をのぞくと、記事数が戦後か ら現在までゆるやかに上昇しているのがわかる。この 50 年間で〈流行〉が見出しに登場した回数は、総数で 2590 回にのぼる。平均すると、1 年間に約 52 回出 現しているということだ。これはちょうど 1 週間に 1 回 という割合になる。

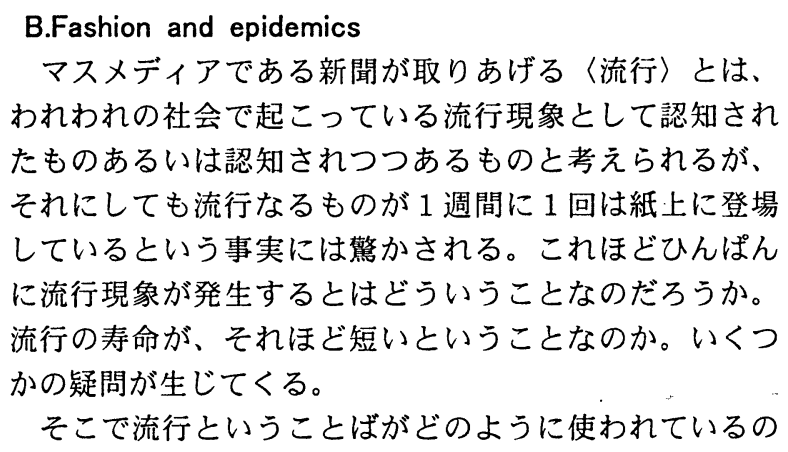
われわれの社会で起こっている流行現象として認知され たものあるいは認知されつつあるものと考えられるが、 それにしても流行なるものが 1 週間に 1 回は紙上に登場 しているという事実には驚かされる。これほどひんぱん に流行現象が発生するとはどういうことなのだろうか。 流行の寿命が、それほど短いということなのか。いくつ かの疑問が生じてくる。

そこで流行ということばがどのように使われているの 
かを見てみよう。まず〈流行〉と見出しに入った記事の 内容をジャンル別に分類して、調べてみた。すると 50 年間に登場した 2590 回もの〈流行〉記事に、実にさ まざまなジャンルの流行現象が登場していることがわか る。それは、約 40 種もの分野にわたっていた。これら を内容別に大きく 3 つのカテゴリーにまとめて分類した 表が、Fig. 2 である。

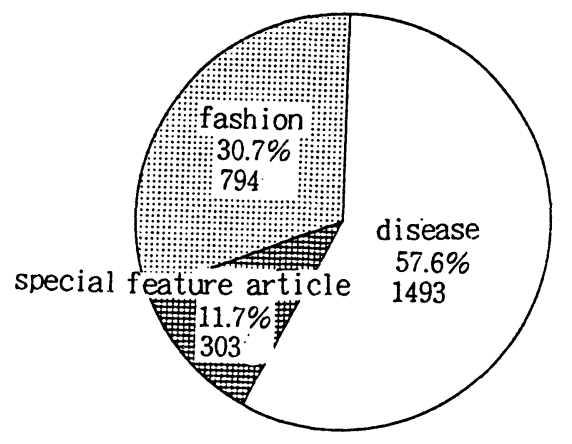

FIG.2. Proportion of 3 categories. Analyzed by author.

ここで注意したいのは、病気の流行が過半数を超え、 6 割近くもあることである。そのあとがファッションを 始めとする一般的流行にまつわる記事で、全体の約 30 \%を占める。そして残りの $13 \%$ 弱が、流行の「特集記 事」となっている。

病気の流行を除いた娛楽、若者文化、ファッションな どごく一般的な流行の出現回数は、23日に 1 回の割合 となっている。およそ 3 週間に 1 回の頻度で、われわれ が普通言うところの新たな流行が紙上に登場しているわ けである。これもまたずいぶん多いという印象をもつだ ろうか。あるいは実感としてあんがい受け入れられる割 合だろうか。

\section{CONCEPT of "epidemics" in natural science}

A. How to use the term "fashion" and "epidemics" 流行ということばが、「病気の流行」という意味で使用 されることが少なからずあることを、われわれは見てき たが、そもそもこのことばの起源はどこにたどれるのだ ろうか。われわれが、ふだん何の疑問も感じることなく 使用している「流行」ということばの本来の意味につい て、視点を変えて検討してみよう。

現代語としての流行ということばは、どのようなニュ アンスで使われているのだろうか。一般的な国語辞典の 中に探ってみた。 ${ }^{2}$ 対象とした 8 冊の国語辞典に共通な キーワードを拾ってみると、「はやり、一時的に、広く」 といった表現が共通していることがわかった。「はやり」 はほとんどが第一義的な説明と並列に並べられて、同義 語あるいは類語として位置づけられていて、ここには「流 行ニはやり」という図式が読み取れる。「はやり」を除け ば、流行とは「(世間に）一時的に広く行われること（ゆ きわたる)」となろう。
流行現象は慣習とともに、社会全体を包む社会規範の 範疇にはいる。そこで慣習と対比することによって、流 行の意味づけを探ってみよう。流行は一般に、「社会的慣 習の文脈の中で、その慣習とは少し異質なものが集団内 に広がる現象をさす」 ${ }^{3}$ と考えられる。つまり慣習と流行 を対比させて考えた場合に、慣習は社会規範や統制の働 きをもつ「固定的」なものであり、逆に、流行は特定の ある時代の中でつねに「流動的」なところにその特性が ある。すなわち慣習が、「持続的」で長期にわたるのに対 して、流行は「短期的」すなわち短命なものである。

流行という表現は医学用語にもあるというか、それは もともと医学用語だったのである。〈流行〉"epidemia"と いう単語は、主として感染性の病気の広がっていくよう すを表すものだった。たとえば、インフルエンザの流行 といった自然現象を表すのに用いられてきたこの専門用 語が、ファッションなど、社会文化的な現象にも流用さ れるようになった。

確かに欧米社会においては、「病気の流行」と「社会文 化的流行」は、それぞれにふさわしい単語を適用するこ とによって明確に区別されている。4一方、日本では、こ の点については、「人為の社会現象としての流行を自然現 象と同一にとらえる日本人的な独特の認識だ」 ${ }^{5}$ と分析す る見方もある。公器であるマスメディアにおいてさえ両 者を区別することなく渾然一体とした使用のされ方をす る。この事実から、〈流行〉に対する日本的なあいまいな 感覚がうかがわれる。日本語がもつ意味籁囲の寛容度の 広さや、ニュアンスの相違といった言語上の理由もあろ う。あるいは「人為の社会現象としての流行」が、自然 現象としての病気の流行ほど重視されない位置にあった ことを物語るものともいえようか。

\section{B. Concept of "epidemics" in medical science}

医学において疾病の流行を扱う領域は、疫学である。 疫学とは医学のうち「ある人間集団にみられる病気の分 布、原因および対策を扱う分野」 6 であり、もっと端的に 言えば「病気の流行現象を扱う分野」`である。

歴史的に見て、疫学は、十九世紀に流行したコレラ、 赤痢、痘そうなどの急性伝染病の研究を中心として確立 されてきた。これは人類の長い歴史の大半が感染症との 戦いであった。この事実を考えれば、必然的に伝染病（感 染症）が疫学の主たる対象ならざるをえなかったことが 理解できよう。

医学における流行とは「特定の感染症がある一定の地

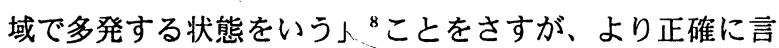
うなら「ある集団内に、同一の疾病が通常の発生頻度を

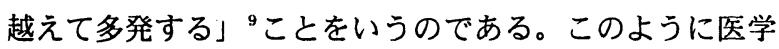
分野の流行は、数量変化に注目し、当然ながら時間的な 推移が重要な前提となる。この点は、社会現象としての 流行と同じ要素をもっていることがわかる。さらに簡潔 に言うなら、時間的推移を基本軸として「一定の集団内、 同一の型、通常頻度以上」の三つのキーワードで表すこ とができる。 


\section{Types of epidemics}

病気の流行の種類を見てみると、同一の感染源に同時 に暴露して（強く接触して）起こる点流行 (pointepidemic) 、またある疾病または病原体が特定地域に長時間、他の 地域よりも常在的に存在する局地的流行 (endemic、別名 地方流行とか風土病的流行ともいわれる)。そして流行の 規模が世界的に拡大した場合を汎流行 (pandemic) と、三 つのタイプに分けられる。医学における通常のこの三分 類は、伝染する地域を一点から小地域、大規模な地域へ と、その地域性を基本軸としていることである。（Fig.3）

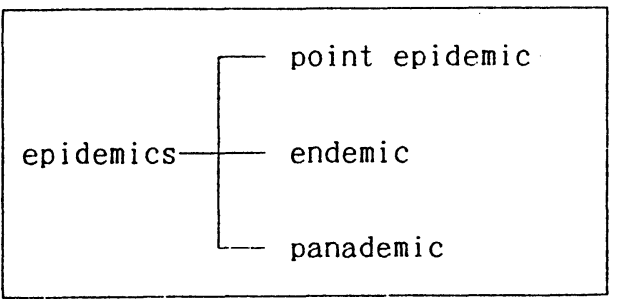

FIG.3. Types of epidemics. Drawn by author on the basis of the preceding researches.

\section{これら三分類とは異なる視点からの分類もある。}

1 つめは「共通経路感染 (common source epidemics)」 と呼ばれるもので、一群の人々が共通の有害な影響に暴 露されたために起こるものである。その中でも特に短期 間で実際上同時に起こるものを曝発流行 (a point source epidemic）という。たとえば学校給食で発生する児童の食 中毒の患者発生数の経時変化に典型的に現れるものがこ れにあたる。2つめは、「連鎖または接触感染 (propagated or progressive epidemics）」と呼ばれるもので、直接的にあ るいは間接的に感染性病原体をもつ宿主から免疫のない 他の宿主へと伝染することによって引き起こされるもの である。

この分類の特徴は、感染の伝播していくスタイルを分 析基準にしている点である。実際の社会現象としての流 行を見るには、これらの分類が有意義な枠組を与えてく れる。

前者の共通経路感染は、テレビの人気番組やC M で新規に用いられる独特のことばが、一気に爆発的に流 行語としてはやる様子を表すことができる。これなどは 曝発流行に極めて類似しているといえよう。また後者の 連鎖・接触感染は、通常の徐々に普及していく一般的な 流行の型を連想させる。（Fig.4）

\section{What is infections?}

感染ということばもまた、流行と同じく日常的になじ みのあるものである。社会科学においても、人々の行動 を分析する場合の概念装置として、後述する「感染説」 とか「社会的感染」という概念がよく使われる。

感染とは、「人体や動物の体内に病原体が侵入し、発育

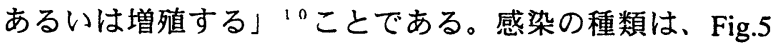
のように、大きく直接伝播と間接伝播の二つに分かれる。

common source epidemics
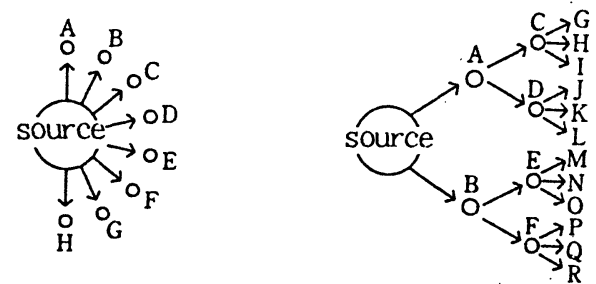

propagated or progressive epidemics

FIG.4. Types of epidemics classified by duffusion style. Drawn by author on the basis of the preceding researches.

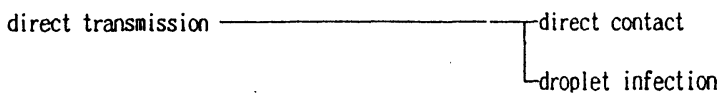

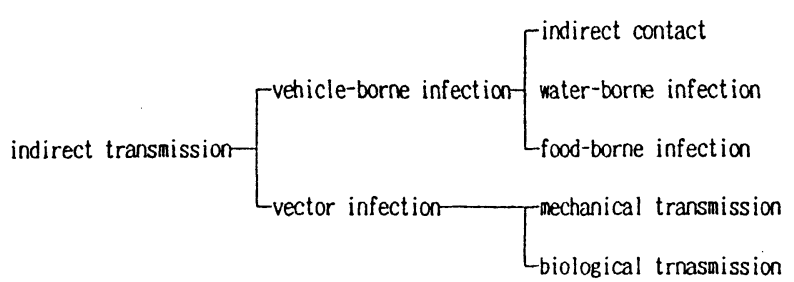

FIG.5.Type of infection. Motonari Fujiwara ed, 1085, Comprehensive Hygiene and Public Health devised 2nd edition, Nankodo, p.179.

直接伝播は接触するか、飛沫感染のように至近距離内 （1メートル以内）のくしゃみとか咳とか会話などによ るすみやかな感染をいう。それに対して間接伝播は、何 かを媒介して感染するもののことである。病気の感染の アナロジーとしての人間行動における感染は、この飛沫 感染のような現象をイメージして使用されているのでは なかろうか。

感染と伝染とは、よく混同されて使われる。実際、今 日の疫学では、感染症と伝染病はほぼ同義語として用い られている。 ${ }^{11}$ 歴史的に見れば伝染 (contagion) というこ とばが先にあり、病原体の発見によって初めて感染 （infection）という概念が生まれた経緯がある。12厳密に は、感染症が宿主への感染という現象に注目したもので あり、「伝染病は病原单から宿主への伝播という現象を重 視した表現である」 ${ }^{13}$ とれている。

このように見てくると、社会現象としての人間の行動、 集団行動などを考える場合、よく使われる感染ではなく、 この伝染の方が二ュアンス的に近いのかもしれない。

\section{E. Susceptibility and resistence}

ところで実社会における流行現象においては、はやり のファッションをすべての人が採用するわけではない。 ある魅力的な流行現象が自分の周りにあったとしても、 
それを採用するか否かは、当事者の意志によるものであ る。この点において、機械的に自然に感染していく病気 の流行とは異なるものではないかという意見も当然出て こよう。

実は病気の流行においても、感染源から発せられた病 原体に接した人すべてが感染するわけではない。病原体 が伝播されても個体によって感受性の差があるためであ る。感受性が大きいと感染しやすく、逆に感受性が全く ない状態を抵抗力があるという。そして特定の感染症に 対して、特異的な作用を示す抗体または細胞を保有する ことによる抵抗力を免疫と呼ぶ。14

このように一見自然現象のように見える病気の流行に おいても、接する個体の感受性の度合いに応じて感染や 非感染が生じるということは、一般の社会現象としての 流行の伝播とも共通する枠組みが提示されよう。つまり 単純な連続的感染と見なされる病気の流行においても、 感受性の度合いという不確定な要素によって、感染する か否かが決定されるわけである。それはちょうど通常の 社会現象としての流行を、個々人が採用するか否かとい う場合の不安定要素である採用者の意志に該当するもの であろうか。

自然現象としての病気の流行と、人為的と思われてい る社会現象としての流行との間においても、この感受性 という不確定要素の視点を導入することによって、より 共通した枠組みで捉えることがある程度可能であろう。

\section{F. Epidemic wave}

医学における流行の科学的研究の成果の一つに、その 経時変化に注目して数量的モデルを構築し、流行してい る伝播過程を見る流行曲線がある。病原体に初感染して から次々と感染して患者数が増えていく様を、時間軸を 基準として新感染者数を表すものである。代表的な流行 曲線が Fig.6である。

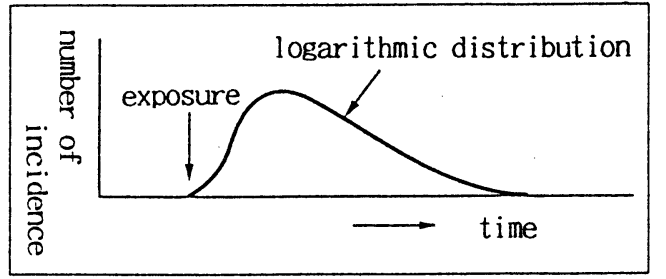

FIG.6. Typical wave in incidence. Katsumi Yoshida and Masayuki Imai, 1990, Hygiene and Public Health Subnote divised 4ed. Nankoudo, p.177

ここから読みとれるのは、ある時点でいつせいに病原 体に接触した時に、その後の患者の発生は時系列的には 対数正規分布となるという現象である。これを利用する と逆に各時点で観測された発生患者数から、その暴露時

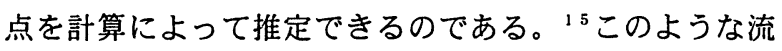

行曲線は、一般の流行現象の伝播過程や普及過程を考え る場合にも応用しうる側面があろう。

感染症の流行曲線の中で有名なものに、Reed-Frost の 流行モデルがある。これは感染源から一定の接触伝染確 率で次々と伝染していく状況をモデル化したものである。 ただし被感染者は、一定期間後には免疫を得て再び感染 しないという前提となっている。これは実際の風疹、麻 疹などの急性感染症にある程度あてはまることが示され ている。 ${ }^{16}$ 病気の流行は感染源、感染経路、感受性保有 者の三要因から成り立つが、この Reed-Frost モデルはこ の三要素を考慮に入れており、すべての病気の流行に適 用できて流行のメカニズムを検討することができる。17 Figure7 は、感受性保有者数 (So) 百名の中へ 1 名の患者 （Co）を投入した有効接触率 (P) $2 \%$ の場合の Reed-frost モデルである。

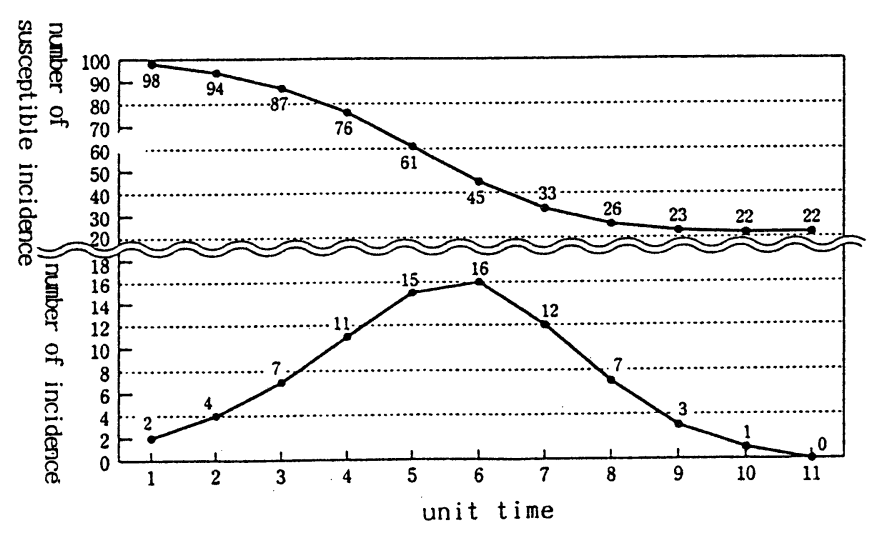

FIG.7. Reed-Frost epidemics wave. Reffered to the following text; Hiroshi Yanagawa ed, 1991,Epidemiology Manual, Nanzando, p.102.

\section{A CONCEPT OF FASHION IN SOCIAL SCIENCE}

A. Wave of fashion in social science

社会科学における流行曲線は、ロジャースの「普及過 程モデル（Fig.8）」が代表的なものである。

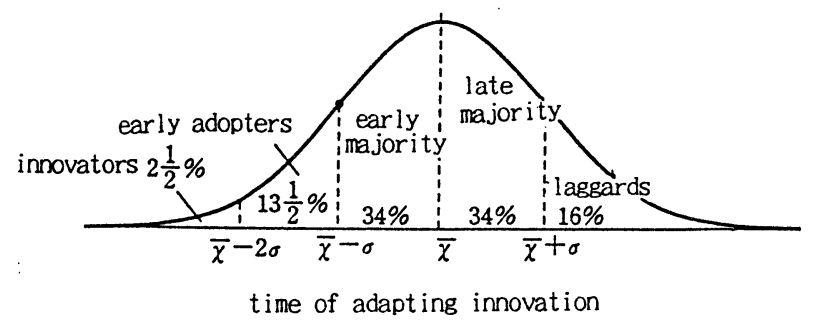

FIG.8. Model for diffusion of innovations by E.M.Rogers. Akira Fujitake translated, 1996, Diffusion ofInnovations, Baihukan, p112 Rogers,E.M,1992,Diffusion of Innovations, The Free Press of Glencoe

これは、イノベーションの採用時期についての時系列 分布図を表したものである。この正規分布となる普及過 程モデルは、一般の流行現象を扱う場合にも時には適用 される。ロジャースの用いたこのモデルは、新たな種類 
のトウモロコシの種が農村地区においてどのように普及 していくか調査して構築したものである。モノでもアイ デアでもイノベーション（人々に新しいと知覚されるア イデア）が採用されて普及していく過程を数量的にモデ ル化し、五段階に分類し、それぞれの数值を具体的に提 示しているところが、大きな特徴となっている。

この普及過程モデルは、人々が新しい型の服装を採用 したりヒット曲を取り入れていく過程を考える場合に、 その時系列の変化と数量的推移を知る上で大きな手がか りを与えてくれるモデルであることは確かであろう。も ちろんこのモデルについて、単純すぎるとか心理的プロ セスが直線的であることに加えて各段階の相互作用とか フィードバックがないといった批判も当然ながらある。 ${ }^{13}$ しかし、ロジャースの意図は、イノベーションの採用の 普及状況といった捉えにくい社会現象を、数量化するこ とによって、普遍性を求めることにあった。

既述した医学の流行曲線とこの普及過程モデルの流行 曲線とを対比してみよう。共通点は共に正規分布を作る ということである。両者とも時系列を軸として、必ずそ のピークと終末を迎える。ピークの中心軸が実際では移 動し曲線も変化するわけだが、基本的にはある程度の比 率で定着することなく下降しつづけて終わる。両者の間 には、さほど相違点は見当らない。

医学の流行モデルでは、伝播していく病原体が寿命を もつ生物であることから、必然的に增加と減少のパター ンを描くことになる。普及過程も単なる物理現象ではな く、イノベーションの採用を意思決定する個人の集まる 集団から成立している。あたかも物理現象であるかのよ うに、イノベーションとなる新製品が市場に満ちて広く ゆきわたる様子は、確実に増加してピークを迎え終末に 至るというパターンを歩む。このような視点から両者の 流行曲線には大きな共通点があることがわかる。

\section{B. Social scentific approch}

医学の分野の中でも、たとえば喫煙行動とか慢性的な 飲酒行動といったような行為が、特定集団の中でどのよ うに伝播していくかといった研究を行う場合は、医学的 というよりも社会学的研究に近くなることがある。たと えば最近の医学の流行研究では、非感染症にも拡大適用 されており、「タバコによる肺癌の流行」という表現など も用いられている。19

Figure9 はヘロイン注射の習性がある町で、ヘロインを 覚えた子どもからある町の子どもに、この習性が伝播し ていく過程を図示したものである。このようなへロイン 使用の流行は、通常の病気の感染の流行とは異なる。身 体に特定の細菌やウィルスが侵入して伝播していくスタ イルの感染に対して、この習性は個人の意思に従って採 用されていく。この例の場合も、習性の伝播という流行 であり、病気の流行ではない。しかしながら、その習性 があたかもウィルスの感染のように次々と伝播していく 様は、まさに病気の感染と同様の経路図が描けるのであ る。

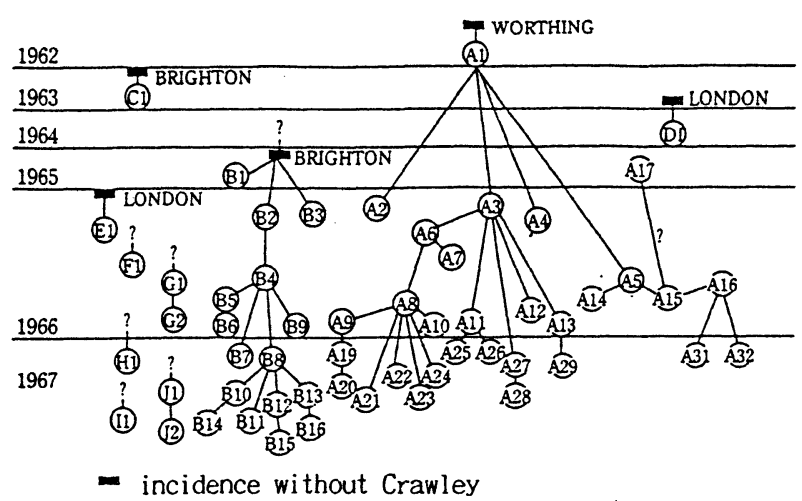

FIG.9. Transmission route of heroin addict intra injection in Epidemiology Text, Nishimurashoten, p.240. (Judith S.

Mausher \& Shira Kramer,1974,Epidemiology-an intorduction text,W. B.Saunders Company)

このような医学関連の研究対象となる特定の習性につ いての感染経路についての研究方法は、通常の社会現象 としての流行を考察する場合にも共通した視点を提供し うるものである。一般的流行でもこのようにいっせいで なく、徐々に感染する遅い流行を考察する場合などには 有効なモデルになるだろう。その意味から医学における このような特定の習性流行の伝播経路研究は、境界領域 的な色合いをもつ分野であると考えられる。

医学において経路伝播図を用いる理由は、曝発的流行 のように同一の感染源にほぼいっせいに暴露して（強く 接触して）一気に多くの人が感染する場合には、数量的 にもモデル化しやすい点にある。先の流行曲線のような モデルで、暴露期や潜伏期間の特定などが比較的容易に できるのである。

しかしながら連鎖感染のようにタイムラグをおいて感 染したり、免疫力の相違により感染速度が異なると、単 純な流行曲線を利用するにはあまりにも多くの媒介変数 が必要となり、数量化にも限界が生じる。そこで複雑な 経路をもつ連鎖感染の場合などには、このような経路伝 播図が有効となってくるのである。

\section{Transmission of information and epidemiological model}

ベイリーは疫学研究の諸文献を整理して、ニつの数学 モデルに分類した。20

一つは決定論的モデルといわれるものである。これは 未感染者数と感染源保菌者数が決定すれば、それ以降の 病気の伝播も一義的に決定するという考え方である。こ れは未感染者が保菌者に接触する比率に基づいてモデル を想定している。その多くは、ロジスティックモデルと してよく知られているものである。

二つめは、確率論的モデルといわれる。これは感染源 を有する人の数ではなく、確率が感染の速度に依存する というものである。

吉田はベイリーのこれらのモデルに従って、各分野で の関連理論を Fig.10のように分類している。 


\begin{tabular}{l|l}
\multicolumn{1}{c|}{ Model of decision thency } & \multicolumn{1}{|c}{ Protability model } \\
\hline Pnoulation model and its application(Biology) & Siaple diffusion proness (Physics) \\
Information arrival in closed grap(Socilology) & Birty and death process(Biology) \\
Diffusion process of consumer goods(Economics) & Ranking of goods(Economics) \\
Political attitude(Politics) & Transmission of information(Medicine) \\
Model of decision theory(Medicine) & -Medical theory and its application-
\end{tabular}

FIG.10. Application of epidemiological model. Masaaki Yoshida, 1971 Transmission of Information in"Lecture of information Science, Vol 12" Kyoritsu Press, P.27.

特に注目すべき点は、疫学理論の応用である決定論的 モデルや確率論的モデルの両者において、情報到達や情 報伝播の研究にも適用できると見ていることである。彼 は「情報の伝播、特に意見態度（宗教・政治上の折伏を 含めて)、風俗習慣上の流行などはほぼ確実にこの模型で 扱うことができる」 ${ }^{21}$ として、「疫学の伝染を情報の伝播 に置き換えることができる」とのべている。22

自然科学の一つである医学によって研究される疫学の 流行研究から、社会科学の流行現象にフィードバックで きるいくつかの概念を概観してきたが、このように感染 源であるAから未感染者である B に伝播しさらにCへと 次々に伝播する経路や、病原体に暴露していっせいに感 染する経路など、一般社会の流行現象を考える場合にも アナロジーとして学べることが多い。医学における病原 体から生体への物理的感染の事実から、一般的流行の社 会的感染という概念への応用は、そのフィールドの違い にも関わらず、そこに共通点を見る人は多いだろう。

\section{COMMON DEFINITION OF FASION}

以上みてきたことからわかるように、流行の一般的意 味づけには共通した枠組がみられる。医学の領域からは、 科学的な流行研究を通して、「一定の集団内、同一の型、 通常頻度以上」という基本枠が提示された。同様に現代 語の規範である辞書的意味からは、「一時的に広くゆきわ たること」という共通した意味づけがなされた。さらに 慣習と対比されることで、流行は「流動的、短期的、拘 束力なし」という特性をもつことがあげられた。さて、 これらのいくつかの流行の定義づけに見られる共通項を 整理してみると、次のようになる。一つには時間を軸と した現象であること。つまり、〈一時的に〉あるいは〈短 期間〉というた時間的特性をもつことである。

また二つめは空間的凝縮性である。〈広くゆきわたる〉 や〈通常頻度以上〉などで表現される地理的あるいは空 間的範囲内での凝縮的特性である。

この考え方にそって流行を定義づけると、一般的に「時 間的、空間的な集中によって起こる社会現象」というこ とになる。もっと端的に、流行は「時・空間の集積現象 である」ともいえよう。

\section{REFERENCES}

${ }^{1}$ The Asahi Database of the headlines used in the Asahi.

${ }^{2}$ Reference to following Japanese Dictionary; Iwanami Japanese Dictionary (1971, Iwanami Shoten), Sanseido Japnese Dictionary (1982, Sanseido), Kadokawa New Japanese Dictionary (1981,Kadokawa Shoten), Kojien (1955, Iwanami Shoten), Daijisen (1995,Shougakkan), Japanese Dicitionary (1995, Koudansha), Koujirin (1976, Sanseido), Gakken Japanese Dictionary (1978, Gakken) .

${ }^{3}$ Akira Yamamoto, 1972, Fashion and psychology of mass in Social Psychology and Mass Communication edited by Akira Yamamoto, Yuhikaku, p.221.

4.For example,"Infection" for disease, "fashion or mode" for costume items, "craze" for tmeporary boom.

${ }^{5}$ Kunihiko Shimonaka,ed, 1985,Heibonsha Encyclopedia Vol.15, p.636 Heibonsha,Ryukou.

${ }^{6}$ Yukihisa Matsumoto and Noritaka Suzuki, 1991, Hygiene/Public health, Ishiyaku Press. p.180.

'Yukihisa Matsumoto and Noritake Suzuki, loc.cit,

${ }^{8}$ Kunihiko Shimonaka, ed,ibid.p.636.

${ }^{9}$ Kazuya Yoshiri ed. 1986, Encyclopedia for health (MEDICA) Vol.6, Gyosei-Press ,p.87, Ryukou.

${ }^{10}$ Itsuzo Shigematsu (translation), 1987, Dictionary of Epidemiology, Japan public health society (John M.Last, 1983,A dictionary of Epidemiology, Oxford University Press).

"Yasugoro Urahisa, 1994, New Public Health, Hiroka Shoten, p.40.

${ }^{12}$ Akiya Kokubo ed. 1980, Public Health ,Asakura Shoten, p.42.

${ }^{13 .}$ Yasugoro Urahisa, Ibid., p.40.

${ }^{14}$ Yoshinori Itogawa, Kazuo Saito, Kazuhiko Sakurai, Tomio Hirahata, 1995, New Hygiene and Public Health revised 2nd edtion, Nankodo, p.55.

${ }^{15}$ Katsumi Yoshida and Masayuki Imai, 1990, Hygiene and Public Health Subnote divised 4th ed. Nankoudo, p.177.

${ }^{16 .}$ Motonori Fujiwara ed. 1985, Comprehensive Hygiene and Public Health 、 Nankoudo, p.177.

"Hiroshi Yanagawa ed, 1991, Epidemiology Manual, Nanzando, p.102.

${ }^{18}$ Yasumasa Tanaka, 1969, Science of Communication, Nihon-Hyoronsha, pp.86-87.

${ }^{19}$ Akiya Koizumi, ed, ibid., p.45.

${ }^{20}$ Masaaki Yoshida, 1971, Transmission of Information, (Lecture of Information Science, Vol. 12) Kyoritsu Press, p.173.

${ }^{21}$ Masaaki Yoshida, ibid., pp.28-29.

${ }^{22}$ Masaaki Yoshisa. ibid., p.37.

${ }^{23}$ Marketing Division of Dentsu ed, 1982, Fashion phenomenon in matured society, Dentsu,p.16. 